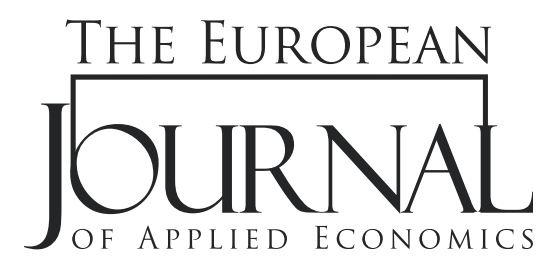

\title{
THE POTENTIAL EFFECTS OF CRYPTOCURRENCIES ON MONETARY POLICY
}

\author{
Nenad Tomić* , Violeta Todorović, Božidar Čakajac \\ Faculty of Economics, \\ University of Kragujevac, \\ Serbia
}

\begin{abstract}
:
All current cryptocurrencies are controlled by private entities, so that the issue of impact on monetary system becomes very important. Autonomous decisions by private entities concerning the money supply could diminish the ability of central banks to implement monetary policy effectively. The subject of this paper is the influence of alternative cryptocurrency forms on the monetary system. The aim of this paper is to determine the ability of central banks to conduct monetary policy successfully in conditions of widespread use of cryptocurrencies in payment transactions. The situation in the cryptocurrency market is compared with the phases of Internet development and the current situation on other markets of electronic payment systems. It is concluded that cryptocurrencies do not have the capacity to endanger the traditional monetary system at the current level. Bearing in mind the early maturity of this market, certain predictions of possible future trends have been made. In the case of private cryptocurrency usage growth, central banks could partially or completely lose influence over monetary policy. The proposed solution is the development of national cryptocurrencies that would ensure the retention of seigniorage to central banks and the prevention of further use of private cryptocurrencies in criminal activities.
\end{abstract}

\section{Article info:}

Received: May 24, 2019

Correction: February 24, 2020

Accepted: February 25, 2020

\section{Keywords:}

monetary policy, cryptocurrencies, stablecoins, private money.

\section{INTRODUCTION}

The application of information and communication technologies (ICT) changed the business model of many activities. The potential impact of intensive ICT application to central banks and the potential for monetary policy management has become a particularly sensitive issue (King, 1999). 
Internet commercialization created infrastructural prerequisites for development and implementation of software electronic money. According to the legal regulation, the licence for issuing electronic money was granted to private entities that met the specified conditions. The possibility to manage the electronic money emission created a real threat that traditional measures of central banks would lose its effectiveness (Goodhart, 2000).

Early e-money operational solutions were of limited duration and had a modest impact. Their influence on the payment system in developed countries was negligible. Therefore, fear of the impact of electronic money seemed to be unjustified during the first decade of the $21^{\text {st }}$ century. However, the Bitcoin emergence and the expansion of alternative forms of cryptocurrencies brought about this issue. It was proved that cryptocurrencies were far more resistant than early electronic money solutions. Due to the great usage of social networks and virality of modern communication, their usage was soon exponentially increased. It should be kept in mind that there was not only an increase in the number of users', but also in the functional diversification of the system.

The subject of this paper is the influence of alternative cryptocurrency forms on the monetary system. Therefore, the effects of private and state cryptocurrencies could be separated. The goal of this paper is to examine the capacity of central banks to conduct monetary policy successfully under conditions of widespread usage of cryptocurrencies. Bearing in mind that the process of monetary regulation is complex even under the existing conditions, the question of whether the inclusion of cryptocurrencies into the monetary system would be a mitigating or aggravating circumstance for monetary policy makers arises.

In the first part of this paper, absolute and relative representation of cryptocurrencies on the global market will be examined. In the second part, the degree to which cryptocurrencies fulfil the money functions will be determined. Based on the first two sections, a conclusion will be drawn concerning to what extent cryptocurrencies affect the monetary system. Their value on the global market is too low, while the number of performed transactions is also at the level that cannot provoke a global shock. Having in mind that this is quite a dynamic category, the possible effects of potential cryptocurrencies' wider usage, or the creation of national cryptocurrencies, will be analysed.

\section{THE CURRENT SHAPE OF THE CRYPTOCURRENCIES' MARKET}

The economic model of cryptocurrencies has its own theoretical foundation in the concept of synthetic commodity money. This concept was formulated by Coase (1972, pp. 143-144) and represents a hybrid form of commodity money and Fiat money. Commodity money is characterized by a limitation in absolute quantity, because its availability depends on the physical limitations of goods which is its basis. The goods used as a base have non-monetary and monetary value. Fiat money is exclusively used for monetary purposes. Furthermore, there is no absolute limitation on the amount available. Since the marginal costs of making new cash are close to zero, central banks could produce it limitlessly, if that had no consequences on monetary system. The possibility of a continual increase in cash offer means that its availability does not have absolute restraint. Therefore, it could be concluded that cash availability is artificially restricted or, so to say, restricted by the will of responsible individuals who manage its emission.

Synthetic commodity money is characterized by an absolute limitation, thus making it more similar to commodity money. At the same time, there is no non-monetary use, which is a characteristic inherent to fiat money. Synthetic commodity money represents the medium of exchange without nonmonetary value, for which the creation of new units has been stopped, or has a growing marginal cost (Selgin, 2014, pp. 93-94). In this sense, an additional issue is economically unjustified, or impossible. 
The abovementioned characteristics will have great importance when considering the impact to the conduct of monetary policy.

Since all cryptocurrencies have been controlled by private entities so far, the issue of influence on the monetary system becomes very important. Theoretically, the autonomous decisions of private entities on money supply would prevent central banks from implementing monetary policy efficiently. However, low market capitalization of cryptocurrencies limits their impact to global monetary movements.

In February 2020, the website coinmarketcap.com registered a total number of 5,134 cryptocurrencies, with only 19 of them having a market capitalization higher than USD 1 billion, and only 65 having a market capitalization higher than 100 million US dollars. The total capitalization of the top 100 cryptocurrencies is lower than 120 billion US dollars, and more than a half of this amount belongs to Bitcoin. Previously stated data indicate that the total capitalization of cryptocurrencies does not change significantly with the increase in their total number.

According to the analysis made by Desjardins (2017), the market capitalization of Bitcoin as a representative cryptocurrency was at about 100 billion US dollars at its peak. This value, although very high in absolute amount, is slightly more than $1.3 \%$ of the world's total cash in circulation (7.6 trillion US dollars), less than $1.3 \%$ of global gold reserves ( 7.7 trillion US dollars), only $0.13 \%$ of the world stocks value ( 73 trillion US dollars), or $0.11 \%$ of the global money supply ( 90.4 trillion US dollars). Bitcoin was used as a representative example because of its higher capitalization in comparison to all other cryptocurrencies together. It should be kept in mind that due to the global fall in the value of all cryptocurrencies in 2018, the share in all observed aggregates would have been much lower. It could be concluded that cryptocurrencies at the current level of usage do not have the capacity to endanger the traditional monetary system.

McCann (2018) made graphical representations of the trend in the total number of Internet users and the total number of all cryptocurrency users. The total number of Internet users in the interval 1990-1995 and total number of cryptocurrency users in the interval 2013-2018 follow almost identical patterns. Not only are the shapes of diagrams are similar, but the absolute numbers are also comparable, since they are twice higher for the Internet users on average. The author concludes that the cryptocurrency market may be dynamic, but is still far from being mature. A similar observation was made by Paul (2017), who states that the cryptocurrencies were in 2017 in the place in which the Internet was in 1994, not only because of the number of users, but also in the sense of content growth. Therefore, in further predictions related to the cryptocurrencies influence, one must keep in mind that the current state is probably just one stage in the evolution process.

\section{FULFILLMENT OF BASIC MONEY FUNCTIONS}

Having achieved unexpectedly high values, certain cryptocurrencies have directed public attention towards the investment aspect. Although many economists treat them as hybrid financial instruments, cryptocurrencies are by their definition a class of electronic money. It is, therefore, necessary to examine to what extent cryptocurrencies fulfill the basic functions of money.

The basic money functions are: medium of exchange, unit of account, and store of value (Mankiw, 2015,82 ). Once again, Bitcoin could be taken as an example. According to the website www.blockchain. com, slightly less than 81.4 million Bitcoin transactions were performed in the year 2018. The website www.bitcoinexchangeguide.com states that their total value was 2.2 trillion US dollars. 
These are very high amounts in absolute terms, but in order to understand their relative importance, it is necessary to make a comparison with some established electronic payment system.

The Visa annual report states that in the period from September 30, 2017 to September 30, 2018, Visa processed 124 billion transactions, with total of about 8.2 trillion US dollars. While there is an obvious difference in transaction numbers, it could be concluded that the values of the total amount are much closer. It should be noted that the total value of Bitcoin transactions is more dependent on the exchange rate to USD than on the transaction number. Thus, the total transaction value in 2017 was 0.87 trillion US dollars while in 2016 it was 0.03 trillion US dollars. Bearing in mind that in 2019, after only a month and a half, the price of Bitcoin was halved, a sharp drop in the annual transaction value could be expected.

In order to completely understand the impact of Bitcoin transactions on the economy, a participant analysis should be made. Most often, participants are individuals who appear in numerous transactions, both as payers and payees. They are traders who frequently purchase and sell in order to make a profit. This increases both the total number and the total amount of transactions, without spreading the scope of the participants.

In order to satisfy the unit of account function, money value should be stable (Marković \& Furtula, 2012, p. 18). Sudden and frequent changes of value expressed in convertible currencies diminish the possibility of its usage as a unit of account. In that case, goods and services change their values too frequently and suddenly, which equally complicates merchants' business and choices of customers. All cryptocurrencies are characterized by unstable values expressed in convertible currencies (US dollar is most commonly used). Bitcoin shows the highest volatility, since it is most often used in speculative transactions. Table 1 displays the annual rate of return for Bitcoin in the period 2011-2018. The table clearly displays the extremely high annual return (both positive and negative) that makes Bitcoin unusable as a long-term unit of account for goods and services.

Table 1: Bitcoin annual rate of return for period 2011-2018 (in US dollars)

\begin{tabular}{cccc}
\hline Year & Opening price & Closing price & Annual return \\
\hline 2011 & 0.30 & 4.72 & $1473 \%$ \\
\hline 2012 & 4.72 & 13.51 & $186 \%$ \\
\hline 2013 & 13.51 & 758 & $5507 \%$ \\
\hline 2014 & 758 & 320 & $-58 \%$ \\
\hline 2015 & 320 & 430 & $35 \%$ \\
\hline 2016 & 430 & 968 & $125 \%$ \\
\hline 2017 & 968 & 13860 & $1331 \%$ \\
\hline 2018 & 13860 & 6321 & $-54 \%$ \\
\hline
\end{tabular}

Source: $h$ ttps://bitcoinexchangeguide.com/bitcoin-btc-proves-to-be-profitable-when-measuring-yearlyreturns-for-investors-2011-2018/

The cryptocurrency value instability could be considered the key factor of their failure to perform the store of value function. The previous table illustrates the annual rates of return, but it does not show monthly changes in value. For example, for the period October 2017 - March 2018, the monthly rates of return were, respectively, $127.81 \%$, then $39.77 \%$, then $-26.65 \%$, then $1.41 \%$, and finally $-32.82 \%$. Individuals or companies that want their wealth to be stable and predictable would not choose to store value in a currency that manifests expressed unpredictability in such a short period of time. In the example of Bitcoin, it could be concluded that cryptocurrencies do not fulfill any of the three basic money functions. 
In the report made for the Committee on Economic and Monetary Affairs of the European Parliament, Claeys, Demertzis \& Efstathiou (2018) state that a medium of exchange needs to be widely used and to have a relatively stable value in order to be considered as money. The cryptocurrencies at this point do not possess any of these characteristics. Lielacher (2019) provides certain projections of Bitcoin user numbers for the end of 2018. A total of 32 million accounts have been created through various digital wallets. This does not mean that these are unique users, because a single user can create multiple personal accounts. In addition, numerous accounts are inactive for a long period of time. It is estimated that 7.1 million of users are active globally. (One should bear in mind that the methodology for determining the level of user activity is debatable; the question arises: is a long-term investor, who bought a certain amount of a cryptocurrency more than a year ago and who has been maintaining that amount, considered active?) Although it is not an insignificant number, it is far below the number of active PayPal users (235 million), MasterCard users (604 million) or Visa users (736 million). The report's authors believe that money should be secured by real assets (e.g., gold) and/or that there is the state coercion so that money could be widely used. In the case of private cryptocurrencies, both conditions are lacking, so not even an increase in user numbers would lead to widespread use of it.

The algorithm creators are aware of the high volatility problem. One of the potential solutions is the cryptocurrency class named "stablecoins". The idea is that the coin supply is adapted to demand in order to achieve stable value. In this way, it is possible to achieve a stable exchange rate against convertible currencies (for example, against the US dollar). An example of stablecoins is Basis. At first, the concept of stable cryptocurrencies may seem a logical solution, but it is economically unsustainable. Namely, all existing cryptocurrencies, including Basis, have been designed with the goal to be globally used. In order to fulfill the money functions, the optimal currency area law must be applicable to all cryptocurrencies, as well as for all other currencies. It is an area in which economic efficiency is maximized if a single currency is used (Mundell, 1961). Since the entire world (or a developed part of the world) could not be an optimal currency area, this means that even the concept of "stablecoins" cannot provide global value stability. In other words, such cryptocurrencies will be fully linked to one convertible currency, but in time their value in other currencies will become more and more unstable. That's why the report's authors consider that it is more appropriate to design a "national cryptocurrency", rather than a global one that adapts only to one national currency.

\section{THE FUTURE OF MONETARY POLICY}

Bitcoin turned 10 on the $1^{\text {st }}$ of January of 2019. Cryptocurrencies at this level of development could not diminish the central banks' ability to conduct monetary policy. Nevertheless, their 10-year existence has changed the approach to electronic money management. The first change relates to the knowledge that private electronic money systems could become long-termed. The Fifth European Union AntiMoney Laundering Directive (Directive 2018/843) refers to cryptocurrencies (which are referred to as "virtual currencies" in the text of the directive, though provisions clearly state what the legislators refer to) and stored value cards. This is an indicator of the seriousness with which regulators will approach these categories in the future. The second change relates to the blockchain as the technological base of cryptocurrencies. It is a technology that has proved to be excellent in preserving large databases so far, because it simultaneously enables mass access while preventing malicious attacks. There is no doubt that, regardless of the fate of first cryptocurrencies which used it, blockchain will become part of the future payment system.

Although existing cryptocurrencies do not have the capacity to influence monetary policy, it could be expected that their presence in the future would increase. Two scenarios are possible: private publishers could create one or more cryptocurrencies that will start to be widely accepted as a means of payment; or some countries could create their own electronic money based on blockchain or related technology. 


\section{Potential Effects of Private Cryptocurrencies}

In 1976, Hayek proposed the creation of competitive supranational currencies that would be used in accordance with the market's principles. He considered that it was necessary to allow the money issuance to the private sector, because national money would always be political money. If certain private currencies proved to be stable, consumers would start using them, and abandon national currencies completely. The emergence of private cryptocurrencies is an attempt to realize this idea. Still, not even one of the multiple cryptocurrencies has succeeded in extruding national currencies, although current events in Venezuela indicate that this moment may not be so far away.

Figure 1 represents so-called "Money Flower". It is a web of sets that define different money forms from the standing of our key aspects: private or public issuer, convertible or non-convertible money, physical or electronic form, indirect transfer with an intermediary, or direct transfer without an intermediary. The space within the sets is the presence of the characteristic listed at the very edge of the set, while all the space outside represents its absence. It is important to pay attention to the theoretical difference between Bitcoin and convertible cryptocurrencies - with the same characteristics when it comes to the mean of transfer and manifestation, the potential convertible cryptocurrencies would be exchangeable with other forms of property by the definition - deposit or cash.

Figure 1: The classification of money forms based on four key aspects, known as the "money flower"

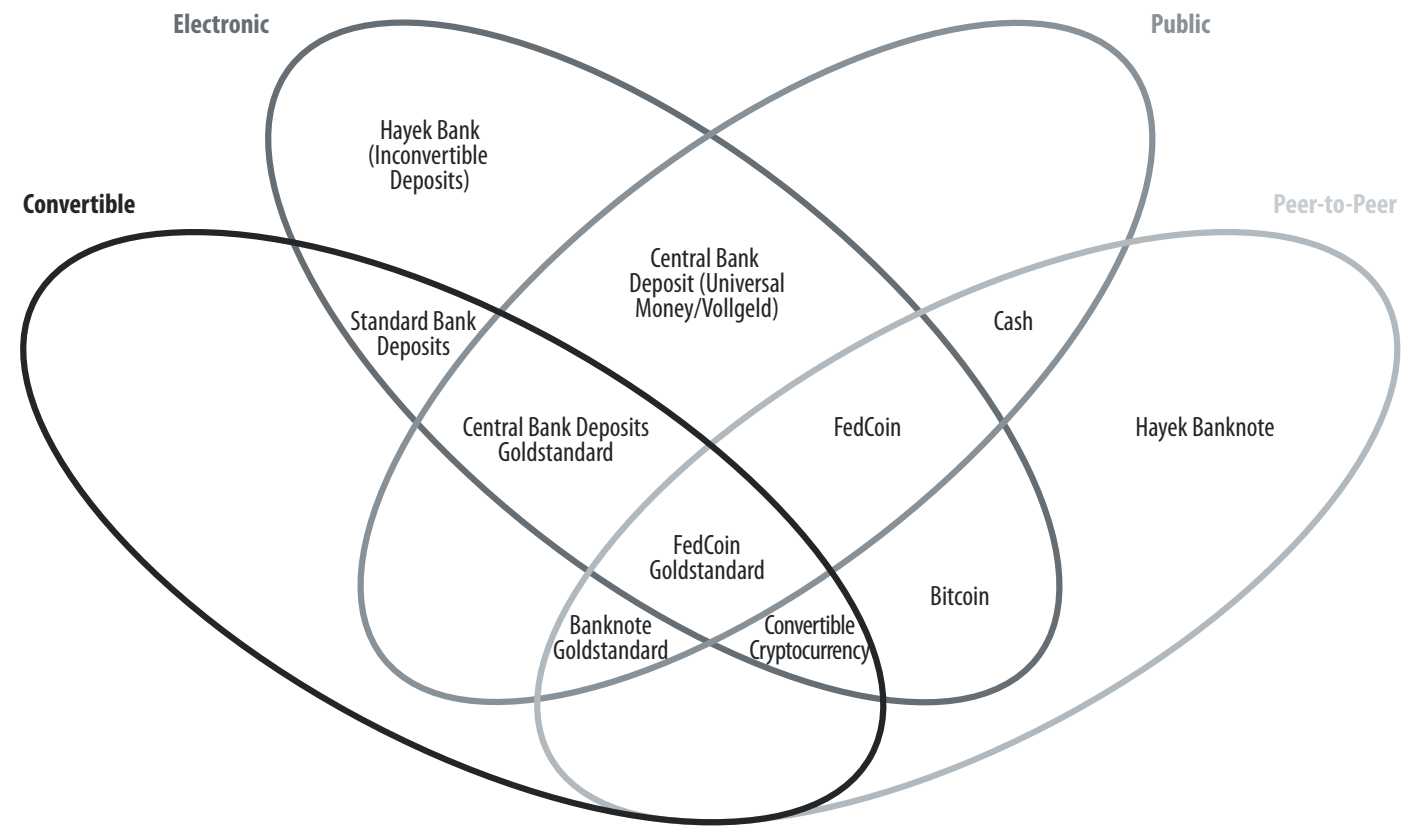

Source: Bech \& Garratt (2017)

Cryptocurrencies have properties which make them a preferable means of payment. They offer a certain degree of anonymity, which is often compared to the degree offered by cash (although the actual anonymity differs among the various cryptocurrencies). Payments are not geographically limited; clearing and settlements are done very quickly. Due to the speed and absence of currency conversion costs, they are particularly suitable for cross-border payments. 
They could be divided into very small parts, which make them suitable for micropayments, so it is expected that they would be more applicable in a modern services-based economic model.

If a cryptocurrency achieved a high rate acceptability in payments, it could easily compete with cash and deposit money for retail payments, as well as traditional electronic payment systems in ecommerce. If the influence on cash is ignored at the moment, it could be concluded that a wider usage of cryptocurrencies could simultaneously reduce the deposit money usage. Cryptocurrency transfers are performed directly between payer and payee through the appropriate infrastructure, but without the participation of intermediaries (He et al., 2017). Settlement of all payments made with deposit money is done through an intermediary (commercial banks), which indicates that users will keep the lower level of deposits in banks. According to the transfer mechanism, cryptocurrencies resemble cash more than deposit money. The final result would be the reduction in bank deposit and erosion of credit potential.

If users use cryptocurrencies to a greater extent, central banks could lose their monopoly over the money supply. In situations where the private sector entity is an issuer of widely accepted electronic money, the central bank partially loses control over reserve requirement system and monetary multipliers, in addition to loss of seigniorage (Sedlarević, Furtula \& Tomić, 2015, pp. 1246-1247). The possibility for managing interest rates was not commented in the paper. However, some authors expressed their fear earlier that interest rate management in these situations would become completely inefficient (Friedman, 2000). If the central bank wants to influence the acceleration or slowdown of economic activities through interest rates, the effect will be limited or completely neutralized by consumers' migration to cryptocurrencies as a means of payment. Further efforts of central banks could be related to the effects on the national currency, which is used less and less, and therefore diminishes the effectiveness of monetary policy. Similar processes were recorded many times in the case of dollarization of monetary systems of small countries. If most of the national financial system is based on foreign currency, monetary policy measures have no impact on economic activity (He, 2018). The same analogy applies to cryptocurrencies, but with the difference that it could also affect developed countries.

Almost all cryptocurrencies that are in use at the moment have a controlled offer. An example is Bitcoin, whose algorithm is programmed to increase the amount of coins at a constant rate, which halves every four years. Others have a completely constant offer, which could be absolutely limited or unlimited. Because of these characteristics, the cryptocurrencies tend to create deflationary effects. In an economic model that relies on cryptocurrencies with such characteristics, the greatest risk would be a deflationary risk. The cryptocurrencies controlled by algorithms do not have the tools to respond to demand shocks, nor to fulfill the lender of last resort function.

\section{The Potential Effects of National Cryptocurrencies}

In the previous section it was explained that cryptocurrencies could be an extremely powerful economic instrument in private hands. States should not be inert during the permanent ICT evolution. Declaring all cryptocurrencies completely illegal and banning their usage would be a very bad solution. States should look at the current trends and consumer preferences. A modern approach is the best defence from innovations that have the potential to reduce the efficiency of the state. Instead of direct battle against cryptocurrencies, states can decide to issue their own operational solutions. The state may have different motives for creating a central bank digital currency (CBDC). One of them is the faster and easier execution of transactions and the almost immediate availability of funds (DeVries, 2016, p. 5). Traditional payment infrastructure is expensive and slow, which is particularly evident in international business. Blockchain-based connectivity has the potential to facilitate business integration by removing the burdens of time-consuming procedures and high currency conversion costs (Team, 2016). 
Motivation may also be the control of the payment system, with the aim of preventing money laundering, terrorist financing, and criminal activities. Countries that depend heavily on remittances from citizens living abroad may be interested in a faster and cheaper inflow of money, unburdened by the high fees paid to remitters. Finally, certain countries may decide to develop a national cryptocurrency due to the desire to overcome economic sanctions or other international barriers.

With regard to the introduction of national cryptocurrencies, a distinction should be made between the situation in which the cryptocurrency completely replaces cash, and the one in which it serves as an addition to the existing payment system. The first situation is unlikely to occur anywhere in the next few years. The closest country to find to such a solution in the future could be Sweden, which announced the complete withdrawal of cash in 2023. One of the elements for such actions should be the introduction of the e-crown, national electronic money that may not necessarily be cryptocurrency (Sveriges Riksbank, 2017). As for the second situation, several countries have either fully implemented certain forms of national cryptocurrencies, or are in the final stages of implementation.

A pioneering venture in this direction is the creation of the national cryptocurrency Petro in Venezuela in late 2018 (Chohan, 2018). It should have served as a mean of safeguarding value (hence, it should have performed one of the basic functions of money) in a situation when the national currency, the Bolivar, lost that function due to excessive inflation as a result of external economic sanctions. Petro's value was supposed to be backed by Venezuela's oil reserves. Strictly speaking, Petro is not a true cryptocurrency, because it is offered through an initial coin offering (ICO), it cannot be mined and the system is controlled in a fully centralized manner. Therefore, Petro can be classified as a digital token, created on the basis of NEM blockchain (Cavicchioli, 2018). In practice, the experiment did not prove successful; the world's largest cryptocurrency exchanges have not accepted to list Petro, and its trade within national borders has remained negligible (Brown, 2019).

Back in 2015, it was announced that Tunisia would be the first country to introduce a national cryptocurrency which would be called eDinar or BitDinar (O'Neal, 2019). The whole project was to be carried out by a national postal company, and was meant to target adults who do not have access to traditional banking services in Tunisia, as well as Tunisian citizens living in Europe. The technical basis should have been provided through the Monetas mobile application. However, the company in charge of developing the application went bankrupt, and the Central Bank of Tunisia became involved in the venture. Although there was some news in November 2019 that the eDinar had finally become operational, the Central Bank of Tunisia denied this, claiming that tests were underway to demonstrate the feasibility of the whole concept (Nelson, 2019).

Numerous other countries have announced that they are considering the introduction of national electronic money, including Dubai within the United Arab Emirates, followed by the Marshall Islands, Senegal, China and Russia (Phillips, 2020). In the case of its implementation in traditional payment infrastructure, the role of central banks and other state bodies would not change significantly. Cash would still exist as an anonymous substitute for electronic payments. In the case of transformation into a completely cashless society, the first step in introducing a national cryptocurrency would be a withdrawal of cash. Since the transactions would be managed by the state through an authorized institution, the motives for the elimination of cash would not be purely monetary. If all payment transactions in the future were made cashless, the state could gain an insight into the overall payment flow of every citizen. Justification of it could be found in the fight against criminal and terrorist activities; however, there is a justifiable fear of civil liberties' loss (Tomić \& Todorović 2018). States could use available information to monitor citizens permanently, while the absolute control of payment transactions could be used to punish disloyal individuals. The impact to monetary policy would depend on the implemented model of cryptocurrency. 
National cryptocurrencies could be stored on a card or in a mobile app (value-based solution), or in a special current account at the centralized institution, which could be an organizational part of the central bank (register-based solution). These two models do not have to be strictly considered as substitutes for cash and deposit money respectively, as deposit money could continue to function simultaneously with one or both of cryptocurrency models. The question arises as to what extent the relative position of the central bank, commercial banks, and end users will change.

There would be no revolutionary changes in the case of replacing cash with value-based cryptocurrency solution. The demand for transactional deposits could fall due to the possibility of remote payments via cryptocurrency applications. A substantial change would occur in the case of implementation of a cryptocurrency register-based solution. Central banks could use interest rates to influence the entire money supply, which would increase monetary policy options. In the case of a general fall in demand and a deep recession, central banks could react with the policy of the negative interest rate (Bofinger, 2018). In the case of cash existence or value-based cryptocurrency, consumers could respond to the fall of interest rates by converting their deposit money to cash or cryptocurrency, in this way remaining beyond the reach of monetary policy. Without cash and value-based cryptocurrency, spending would be the only way to prevent long-term loss of owners' assets.

If the current account opening is generally available to everyone, depositors would transfer all funds to central banks through accounts of secured deposits. Furthermore, the chances of a "digital run on banks" would increase. If the central bank conducts a different interest rate policy on deposit money and cryptocurrencies, consumers could easily decide to transfer all funds to the central bank. The space for commercial bank activities would be significantly narrowed, so these banks would be forced to obtain the missing liquid funds from non-depository sources.

\section{CONCLUSION}

Cryptocurrencies currently do not have the capacity to endanger the international monetary system. This does not mean that their emergence is completely irrelevant to the monetary policy creators. If one considers the market maturity and constant increase in the number of participants, it may be concluded that, at some point in the foreseeable future, cryptocurrencies could affect certain aspects of monetary policy. Central banks in countries with unstable national currencies would experience such problems before others. Something similar is already happening now in Venezuela. Causes for this behavior do not have to be necessarily monetary - so individuals can opt to transfer their assets into private cryptocurrencies for privacy reasons to avoid transaction tracking. In this case, even the central banks in countries with stable currencies could experience problems.

A reduction or complete loss of influence on monetary policy would lead to the deepening of economic problems. The basic approach against monetary control loss is to conduct a principled, responsible, and unwavering monetary policy. Maintaining the neutrality of the central bank and depoliticizing monetary policy are clear institutional assumptions. At the same time, the central bank must be open to new ideas and trends. The growing pressure of accepted private cryptocurrencies will not be solved by ignoring reality and by simply banning their use. After an adequate analysis, it should be determined in which percentage cryptocurrencies are really used for criminal and terrorist activities. Measures to prevent such behavior should be defined after. This would stop the additional mystification of private cryptocurrencies.

At this point, issuing their own electronic money seems to be the ultimate solution for all central banks. It does not necessarily have to be technologically close to current cryptocurrencies. It must be some kind of "stablecoin", that is, it must be based on adaptable protocol. Previous claims that global cryptocurrencies could not be adjusted equally to every national currency is in favor of this idea. 
With the issuance of their own electronic money, states would avoid the possibility of the emergence of a powerful private issuer in the shape of a consortium of IT companies, websites, and banks. They would also ensure the effectuation of "digital seigniorage", which could fund their further activities.

The research limitation originates from the very nature of cryptocurrencies. Due to the instability of its value, the relation of market capitalization and monetary aggregates and total value of transactions could change significantly on the weekly basis. All indicators referring to cryptocurrencies should be tied strictly to the time period in which they were determined, and they should not be considered stable. In terms of analyzing cryptocurrencies with monetary policy, research should be understood as a set of assumptions that could be modified under the influence of new knowledge. Therefore, in the following research studies, steps of the states which announce the project of cash limitation and cash withdrawal should be taken into consideration. The questions of the introduction of national currencies is inextricably linked to the issue of cash withdrawal, so these two processes should be analyzed simultaneously.

\section{REFERENCES:}

Bech, M. L. \& Garratt, R. (2017). Central bank cryptocurrencies. BIS Quarterly Review - September. 55-70 Bofinger, P. (2018). Digitalisation of money and the future of monetary policy. Vox - CEPR Policy portal. Brown, A. (2019). Venezuela's Failed Cryptocurrency Is the Future of Money. Bloomberg. May $10^{\text {th }}$ Cavicchioli, M. (2018). The difference between Token and Cryptocurrency. Medium. August $1^{\text {st }}$

Chohan, U.W. (2018). Cryptocurrencies as Asset-Backed Instruments: The Venezuelan Petro. SSRN electronic journal, February 2018. Available at: https://ssrn.com/abstract=3119606 or http://dx.doi.org/10.2139/ssrn.3119606

Claeys, G., Demertzis, M. \& Efstathiou, K. (2018). Cryptocurrencies and monetary policy. Policy Department A at the request of the Economic and Monetary Affairs Committee. June

Coase (1972) Durability and monopoly. Journal of Law and Economics, 15(1), 143-149. DOI: 10.1086/466731

Desjardins, J. (2017). Comparing the world's money and markets. The Money Project, available at https://money. visualcapitalist.com/worlds-money-markets-one-visualization-2017/

European Commission (2009) Directive 2018/843 amending Directive (EU) 2015/849 on the prevention of the use of the financial system for the purposes of money laundering or terrorist financing, and amending Directives 2009/138/EC and 2013/36/EU, Official Jounrnal of European Union, L series

Friedman, B. M. (2000). Decoupling at the Margin: The Threat to Monetary Policy from the Electronic Revolution in Banking. International Finance 3(2), 261-272. DOI: 10.3386/w7955

Marković, D. \& Furtula, S. (2012). Monetarna ekonomija. Kragujevac: Ekonomski fakultet Univerziteta u Kragujevcu

Goodhart, C. (2000). Can Central Banking Survive the IT Revolution? International Finance, 3 (2), 189-209. DOI: $10.1111 / 1468-2362.00048$

Hayek, F. A. (1976). The denationalization of money. London: Institute for Economic Affairs

He, D., Ross L., Vikram H., Tommaso M. G., Nigel J., Mikari K., Tanai K., Céline R. \& Hervé T. (2017). Fintech and Financial Services: Initial Considerations. IMF Staff Discussion Note 17/05. Washington DC: International Monetary Fund

He, D. (2018). Monetary policy in digital age. Finance \& Development, 55(2), 14-16.

King, M. (1999). Challenges for Monetary Policy: New and Old. Symposium on New Challenges for Monetary Policy. Federal Reserve Bank of Kansas City, Jackson Hole, Wyoming, August 27

Lielacher, A. (2019). How Many People Use Bitcoin in 2019?. Bitcoin Market Journal, February $11^{\text {th }}$

Mankiw, G. (2015). Macroeconomics (9 $9^{\text {th }}$ edition). New York, NY: MacMillan education

Mundell, R. A. (1961). A Theory of Optimum Currency Areas. American Economic Review, 51(4), 657-665.

McCann, C. (2018). 12 Graphs That Show Just How Early The Cryptocurrency Market Is. Medium.com, May $6^{\text {th }}$ 
Nelson, D. (2019) Tunisia's Central Bank Denies Reports Claiming It Issued an E-Dinar. Coindesk, November $12^{\text {th }}$

O'Neal, S. (2019) CBDCs of the World: The benefits and drawbacks of national cryptos, according to different jurisdictions. Cointelegraph, June $19^{\text {th }}$

Paul, A. (2017). It's 1994 in Cryptocurrency. Forbes, November 27 th

Phillips, G. (2020) These 6 Countries Want a National Cryptocurrency. Blocksdecoded.com, February $11^{\text {th }}$

Sedlarević, L.., Furtula, S. \& Tomić, N. (2015). Potencijalni efekti elektronskog novca na monetarnu politiku. Teme, 39(4), 1235-1255

Selgin, G. (2014). Syntetic commodity money. Journal of Financial Stability, 17(C), 92-99. DOI: 10.1016/j. jfs.2014.07.002

Sveriges Riksbank (2017). The Riksbank's e-krona project. Report 1, September

Team, B. (2016, January 20). Understanding Bitcoin's Growth in 2015. Retrieved from Bitpay Website: https://blog.bitpay.com/understanding-bitcoins-growth-in-2015/

Tomić, N. \& Todorović, V. (2018) Challenges of transition to cashless society, in: Babić, V. (ed.) Contemporary issues in economics, business and management, 313-320

Visa Annual report 2018

https://bitcoinexchangeguide.com/bitcoin-btc-proves-to-be-profitable-when-measuring-yearly-returns-forinvestors-2011-2018/ (accessed on 10 May 2019)

https://bitcoinexchangeguide.com/bitcoin-btc-transaction-volume-in-2018-surpasses-paypals-performance-viasatoshi-capital-data/ (accessed on 12 May 2019)

https://www.blockchain.com/en/charts/n-transactions-total (accessed on 12 May 2019)

https://coinmarketcap.com/ (accessed on 18 Febrary 2020) 


\section{POTENCIJALNI EFEKTI KRIPTOVALUTA NA MONETARNU POLITIKU}

\section{Rezime:}

Sve aktuelne sisteme kriptovaluta kontrolišu privatni entiteti, pa pitanje uticaja na monetarni sistem postaje veoma važno. Autonomne odluke privatnih entiteta o ponudi novca mogle bi umanjiti sposobnost centralnih banaka da efikasno sprovode monetarnu politiku. Predmet istraživanja rada je uticaj alternativnih oblika sistema kriptovaluta na monetarni sistem. Cilj rada je utvrđivanje sposobnosti centralnih banaka da uspešno vode monetarnu politiku u uslovima široke upotrebe kriptovaluta u platnom prometu. U radu je stanje na tržištu kriptovaluta upoređeno sa fazama razvoja interneta i trenutnim stanjem na tržištu drugih elektronskih sistema plaćanja. Zaključeno je da kriptovalute na sadašnjem nivou upotrebe nemaju kapacitet da ugroze tradicionalni monetarni sistem. Imajući u vidu ranu zrelost ovog tržišta, izvršena su i određena predviđanja mogućih tendencija. U slučaju rasta upotrebe privatnih kriptovaluta, može se dogoditi da centralne banke delimično ili potpuno izgube uticaj na monetarnu politiku. Predloženo rešenje je razvoj nacionalnih kriptovaluta, koje bi osigurale zadržavanje sinjoraže centralnim bankama i sprečile mogućnost dalje upotrebe privatnih kriptovaluta u kriminalnim aktivnostima.
Ključne reči:

monetarna politika, kriptovalute, stabilne kriptovalute, privatni novac. 